\title{
An In Vitro Study of Fungicide Effects on Pollen Germination and Tube Growth in Almond
}

\author{
Weiguang $\mathbf{Y i}^{1}$, S. Edward $\mathbf{L a w}^{2}$, and Hazel Y. Wetzstein ${ }^{1,3}$ \\ The University of Georgia, Athens, GA 30602
}

Additional index words. Prunus dulcis, pollen tube morphology results (Church and Williams, 1977). The objective of the current study was to evaluate the effects of selected fungicides on pollen germination and tube growth in almond using in vitro assays. Results of this screening will be used in further laboratory and field studies to assess pollen function in vivo.

\section{Materials and Methods}

Almond pollen was collected from 'Butte' trees in Bakersfield, Calif. To maintain viability, pollen was stored at $-20^{\circ} \mathrm{C}$ until use. Ten fungicides applied to almond during the blooming season were selected for study: 1) myclobutanil, Rohm and Haas Co., Philadelphia; 2) propiconazole, Novartis Crop Protection, Greensboro, N.C.; 3) benomyl, DuPont, Wilmington, Del.; 4) thiophanate-methyl, Elf Atochem North America, Philadelphia; 5) iprodione, Aventis CS, Research Triangle Park, N.C.; 6) captan, Micro Flo Co., Memphis, Tenn.; 7) maneb, Griffin L.L.C., Valdosta, Ga.; 8) ziram, Elf Atochem North America; 9) cyprodinil, Novartis Crop Protection; 10) azoxystrobin, Zeneca Agricultural Products, Wilmington, Del. The class, trade name, formulation, and recommended field rate for each of the compounds are shown in Table 1. Pollen germination and tube growth were conducted at three concentrations: the recommended field rate (100\% RFR), $10 \%$ RFR, and 1\% RFR of each fungicide. In fungicides where a range of rates was recommended, an average concentration of upper and lower values was used. Germination medium without fungicide served as control.

Pollen germination medium consisted of a solution of $12 \%$ sucrose (w/v), $0.062 \%$ $\mathrm{CaNO}_{3}(\mathrm{w} / \mathrm{v})$, and $0.024 \%$ boric acid (w/v). Assays were conducted in tissue culture plates (Falcon Microtest III, Lincoln Park, N.J.). For each assay, $200 \mu \mathrm{L}$ of medium with or without fungicide was placed into each well. About 400 pollen grains were inoculated uniformly into each well. To insure proper mixing of pollen and germination medium, the contents of each well were agitated by repeatedly drawing and expelling the contents through a $200-\mu \mathrm{L}$ micropipette. Culture plates were placed into a dark incubator at $27^{\circ} \mathrm{C}$. After $2.5 \mathrm{~h}, 20 \mu \mathrm{L}$ of HistoChoice (Amresco, Solon, Ohio) fixagermion, fruit set, and/or yield in tree fruit crops. Reports include those for apple (Malus $\times$ domestica Borkh.) (Church and Williams, 1977; Legge and Williams, 1975), mango (Mangifera indica L.) (Dag et al., 2003), pear (Pyrus communis L.) (Butt et al., 1985; Marcucci and Filiti, 1984; Mayer and Lunden, 1986), pecan (Carya illinoensis Wangenh C. Koch) (He and Wetzstein, 1994; Wetzstein, 1990), and sweet cherry (Prunus avium L.) (Eaton, 1961). Effects of fungicides on pollen germination and growth in almond are little known. Particularly with the advent

Received for publication 28 May 2002. Accepted for publication 16 Dec. 2002. We thank Gwen Hirsch for technical assistance.

${ }^{1}$ Dept. of Horticulture.

${ }^{2}$ Dept. of Biological and Agricultural Engineering.

${ }^{3}$ To whom reprint requests should be sent. E-mail address: hywetz@uga.edu

\begin{tabular}{|c|c|c|c|c|c|c|}
\hline $\begin{array}{l}\text { Active } \\
\text { ingredient }\end{array}$ & Class & $\begin{array}{l}\text { Trade } \\
\text { name }\end{array}$ & Formulation ${ }^{2}$ & $\begin{array}{c}\text { Active } \\
\text { ingredient } \\
(\%)\end{array}$ & $\begin{array}{c}\text { RFR } \\
(\text { per acre) })^{y}\end{array}$ & $\begin{array}{c}\text { Lab } \\
\text { equivalent }^{\mathrm{x}}\end{array}$ \\
\hline Myclobutanil & Azole & Rally & WSP & 40.0 & $1.625 \mathrm{oz}$ & $0.24 \mathrm{mg} \cdot \mathrm{mL}^{-1}$ \\
\hline Propiconazole & Azole & Break & $\mathrm{EC}$ & 41.8 & $4 \mathrm{oz}$ & $0.63 \mathrm{~mL} \cdot \mathrm{L}^{-1}$ \\
\hline Benomyl & Benzimidazole & Benlate & SP & 50.0 & $20 \mathrm{oz}$ & $3.0 \mathrm{mg} \cdot \mathrm{L}^{-1}$ \\
\hline \multicolumn{7}{|l|}{ Thiophanate } \\
\hline -methyl & Benzimidazole & Topsin M & WSP & 70.0 & $1.5 \mathrm{lb}$ & $3.6 \mathrm{mg} \cdot \mathrm{mL}^{-1}$ \\
\hline Iprodione & Dicarboximide & Rovral & Powder & 50.0 & $1 \mathrm{lb}$ & $2.4 \mathrm{mg} \cdot \mathrm{mL}^{-1}$ \\
\hline Captan & Dicarboximide & Captan & WP & 48.9 & $6.5 \mathrm{lb}$ & $15.6 \mathrm{mg} \cdot \mathrm{mL}^{-1}$ \\
\hline Maneb & Dithiocarbamate & Manex & Flowable & 37.0 & $5.6 \mathrm{qt}$ & $28.0 \mathrm{~mL} \cdot \mathrm{L}^{-1}$ \\
\hline Ziram & Dithiocarbamate & Ziram & WG & 76.0 & $8 \mathrm{lb}$ & $19.2 \mathrm{mg} \cdot \mathrm{mL}^{-1}$ \\
\hline Cyprodinil & Pyrimidine & Vangard & WG & 75.0 & $7.5 \mathrm{oz}$ & $1.1 \mathrm{mg} \cdot \mathrm{mL}^{-1}$ \\
\hline Azoxystrobin & Strobilurin & Abound & Flowable & 22.9 & $7.7 \mathrm{oz}$ & $1.2 \mathrm{~mL} \cdot \mathrm{L}^{-1}$ \\
\hline
\end{tabular}

${ }^{2} \mathrm{WSP}=$ water-soluble pouches; $\mathrm{EC}=$ emulsifiable concentrate; $\mathrm{SP}=$ wettable powder in water-soluble film; WP = wettable powder; WG = water-dispersable granule.

y Recommended field rates in the amount of commercial formulation of fungicides per acre.

${ }^{\mathrm{x}}$ Fungicide concentrations in medium were calculated based on a 50-gallon spray volume per acre. 
Table 2. Germination of almond pollen in presence of selected fungicides. ${ }^{z}$

\begin{tabular}{lccc}
\hline & \multicolumn{3}{c}{$\begin{array}{c}\text { Fungicide concn } \\
\text { (\% of RFR) }\end{array}$} \\
\cline { 2 - 4 } Fungicides & 100 & 10 & 1 \\
\hline No-fungicide control & $100 \mathrm{a}^{\mathrm{y}}$ & $100 \mathrm{a}$ & $100 \mathrm{a}$ \\
Propiconazole & $0.0 \mathrm{~b}$ & $8.0 \mathrm{~cd}$ & $103.9 \mathrm{a}$ \\
Benomyl & $---\mathrm{x}$ & --- & $96.3 \mathrm{a}$ \\
Myclobutanil & $0.0 \mathrm{~b}$ & $58.3 \mathrm{~b}$ & $76.4 \mathrm{~b}$ \\
Iprodione & $0.0 \mathrm{~b}$ & $11.2 \mathrm{c}$ & $62.9 \mathrm{c}$ \\
Thiophanate-methyl & --- & --- & $59.4 \mathrm{~cd}$ \\
Maneb & $0.0 \mathrm{~b}$ & $0.0 \mathrm{~d}$ & $50.7 \mathrm{~d}$ \\
Cyprodinil & $0.0 \mathrm{~b}$ & $0.0 \mathrm{~d}$ & $30.2 \mathrm{e}$ \\
Ziram & $0.0 \mathrm{~b}$ & $0.0 \mathrm{~d}$ & $18.8 \mathrm{e}$ \\
Azoxystrobin & $0.0 \mathrm{~b}$ & $0.0 \mathrm{~d}$ & $0.6 \mathrm{f}$ \\
Captan & $0.0 \mathrm{~b}$ & $0.0 \mathrm{~d}$ & $0.2 \mathrm{f}$ \\
\hline
\end{tabular}

${ }^{\mathrm{z}}$ Germination percentages shown are relative to the control, which is expressed as $100 \%$. Actual pollen germination in the no-fungicide control was $53.7 \%$. $\mathrm{RFR}=$ recommended field rate.

${ }^{y}$ Mean values within a column followed by the same letter are not significantly different at $P=$ 0.05 , Duncan's multiple range test.

${ }^{\mathrm{x}}$ Not counted because of interference of particulate materials from the fungicide.

tive was added into each assay well to arrest tube growth and preserve tube morphology. Culture plates were examined using an inverted microscope (Nikon, Garden City, N.Y.). Pollen was counted as germinated if tube extension was greater than the diameter of pollen grains. Tube lengths of germinated pollen grains were measured using a gridded ocular. Average tube lengths were calculated from measurements of randomly selected 50 pollen grains.

A factorial design was used in this study. Each treatment ( 10 fungicides $\times 3$ concentrations plus control) was replicated 5 times. Statistical analysis was conducted using Duncan's multiple range test within the general linear model procedure of SAS (SAS Institute, 1989). For germination percentage, data were transformed with arcsine to meet the equal variance assumption (Gomez and Gomez, 1984).

\section{Results and Discussion}

Germination. Relative germination percentage was calculated based on the formula: (\% germination in treatment $/ \%$ germination in control) $\times 100$. Relative germination percentages for pollen with different concentrations of fungicide are shown in Table 2. No pollen germination was observed in assays incorporating any of the fungicides at $100 \%$ RFR. This was in contrast to the control, which showed $53.7 \%$ germination. Pollen grains typically exhibit high sensitivity to chemicals with in vitro germination assays where contact with chemicals is intense. Although germination was inhibited severely at $10 \%$ RFR, the fungicides showed differential effects as pollen germination was observed in the presence of maneb, cyprodinil, ziram, azoxystrobin, and captan. Germination in propiconazole and iprodione was only $8 \%$ and $11 \%$ of the control, respectively. The highest relative germination occurred in the presence of myclobutanil, which was $58.3 \%$ of the control. No data were taken for the two highest concentrations of benomyl and thiophanate-methyl, because particulate

Table 3. Tube growth of almond pollen germinated in medium containing selected fungicides.

\begin{tabular}{lccc}
\hline & \multicolumn{3}{c}{ Tube length $(\mu \mathrm{m})^{\mathrm{z}}$} \\
\cline { 2 - 4 } Fungicide & $100 \%$ RFR & $10 \%$ RFR & $1 \%$ RFR \\
\hline No-fungicide control & $504 \mathrm{a}$ & $504 \mathrm{a}^{\mathrm{y}}$ & $504 \mathrm{a}$ \\
Propiconazole & $0 \mathrm{~b}$ & $93 \mathrm{~d}$ & $422 \mathrm{a}$ \\
Benomyl & $---\mathrm{x}^{\mathrm{x}}$ & --- & $453 \mathrm{a}$ \\
Myclobutanil & $0 \mathrm{~b}$ & $349 \mathrm{~b}$ & $459 \mathrm{a}$ \\
Iprodione & $0 \mathrm{~b}$ & $202 \mathrm{c}$ & $442 \mathrm{a}$ \\
Thiophanate-methyl & --- & --- & $403 \mathrm{a}$ \\
Maneb & $0 \mathrm{~b}$ & $0 \mathrm{e}$ & $165 \mathrm{~b}$ \\
Cyprodinil & $0 \mathrm{~b}$ & $0 \mathrm{e}$ & $163 \mathrm{~b}$ \\
Ziram & $0 \mathrm{~b}$ & $0 \mathrm{e}$ & $107 \mathrm{c}$ \\
Azoxystrobin & $0 \mathrm{~b}$ & $0 \mathrm{e}$ & $50 \mathrm{~d}$ \\
Captan & $0 \mathrm{~b}$ & $0 \mathrm{e}$ & $53 \mathrm{~d}$ \\
\hline
\end{tabular}

${ }^{\mathrm{z}}$ Mean length of pollen tubes germinated in medium with fungicide concentration of $100 \%, 10 \%$, or $1 \%$ recommended field rate (RFR). Length was measured $2.5 \mathrm{~h}$ after inoculation.

'Mean values within a column followed by the same letter are not significantly different at $P=0.05$, Duncan's multiple range test.

${ }^{x}$ Not measured because of interference of particulate materials from the fungicide.

materials of the fungicide formulations obscured counting.

Assays conducted at $1 \%$ RFR were effective in delineating differences in almond pollen sensitivity to different fungicides (Table 2). Captan and azoxystrobin remained extremely inhibitory, with germination less than $1 \%$ of the control. Ziram and cyprodinil were also strongly inhibitory. In contrast, germination did not differ from the control when propiconazole or benomyl was incorporated into the medium. Pollen germination in the presence of myclobutanil exhibited slight but significant inhibition at $76 \%$ that of the control. Intermediate inhibitory effects on pollen germination were observed with maneb, thiophanate-methyl, and iprodione, with relative germination ranging from $51 \%$ to $63 \%$.

The inhibitory effects of captan, benomyl, and thiophanate-methyl used in the present study were also observed in apple pollen germinated in vitro (Church and Williams, 1977). Likewise, captan was reported to inhibit pollen germination in pear (Butt et al., 1985). Ziram was also found to inhibit pollen germination in lowbush blueberry (Vaccinium angustifolium Ait.) (Lockhart, 1967). In pecan, propiconazole, thiophanate-methyl, and benomyl were reported to inhibit pollen germination (He and Wetzstein, 1994). From our test results, the two new azole products, propiconazole and myclobutanil, had little or no inhibition, while the other new product, azoxystrobin, had very toxic effects. This illustrates the potential usefulness of in vitro assays for evaluating new chemicals.

Tube growth. In general, the fungicides that had the greatest inhibition on pollen germination also had the greatest inhibitory effects on tube growth (Table 3). Of the few pollen grains that germinated with captan and azoxystrobin at $1 / 100$ RFR, tube length was only $10 \%$ of the control. Tube lengths of pollen germinated in the presence of propiconazole, benomyl, myclobutanil, iprodione, or thiophanate-methyl at $1 \%$ RFR were not significantly different from those of the control. This was the case even though myclobutanil, iprodione, and thiophanate- methyl significantly inhibited pollen germination percentages (Table 2). Intermediate inhibitory effects on tube length were observed with maneb, cyprodinil, and ziram (Table 3), where pollen exhibited $32 \%$, $32 \%$, and $21 \%$ of the tube length of controls, respectively.

In general, pollen tube growth was less affected by the presence of fungicide than was pollen germination. In pollen that did germinate, tube elongation was no different from controls in five of the fungicides evaluated even though pollen grains were in continuous contact with fungicides under in vitro assay conditions. Nonetheless, some chemicals reduced tube elongation by $\approx 90 \%$. Captan and azoxystrobin were extremely inhibitory to both pollen germination and tube growth.

Tube morphology. In addition to inhibiting pollen germination and tube elongation, some fungicide treatments also influenced tube morphology. Pollen germinating in the absence of fungicides had tubes that were straight, long, and smooth with tapering ends (Fig. 1A). Pollen tubes grown in the presence of benomyl exhibited tube length similar to the control. However, some pollen tubes were characterized by swelling and rupture in the tip region (Fig. 1B). In the presence of myclobutanil, pollen tubes exhibited abnormal growth, with tubes changing direction during extension (Fig. 1C). Pollen tubes that grew in the presence of propiconazole had a sinuous, wavy configuration (Fig. 1D).

Some fungicides have been shown to exhibit marked effects on plant developmental processes, including those on vegetative and reproductive structures (Koller, 1987; Wetzstein et al., 2002). Propiconazole altered cell arrangement in leaves of pecan shoots (Wetzstein et al., 2002). Benomyl induced abnormal pollen tube morphology and microtubule organization. In Tradescantia virginiana L., benomyl induced pollen tube rupture in the apical region (He et al., 1996), which is similar to the phenomenon observed in the current study. Also in T. virginiana, He et al. (1995) reported propiconazole inhibited cytoplasmic streaming, induced abnormal tube morphology and cytoskeletal distribution, and affected both microfilaments 


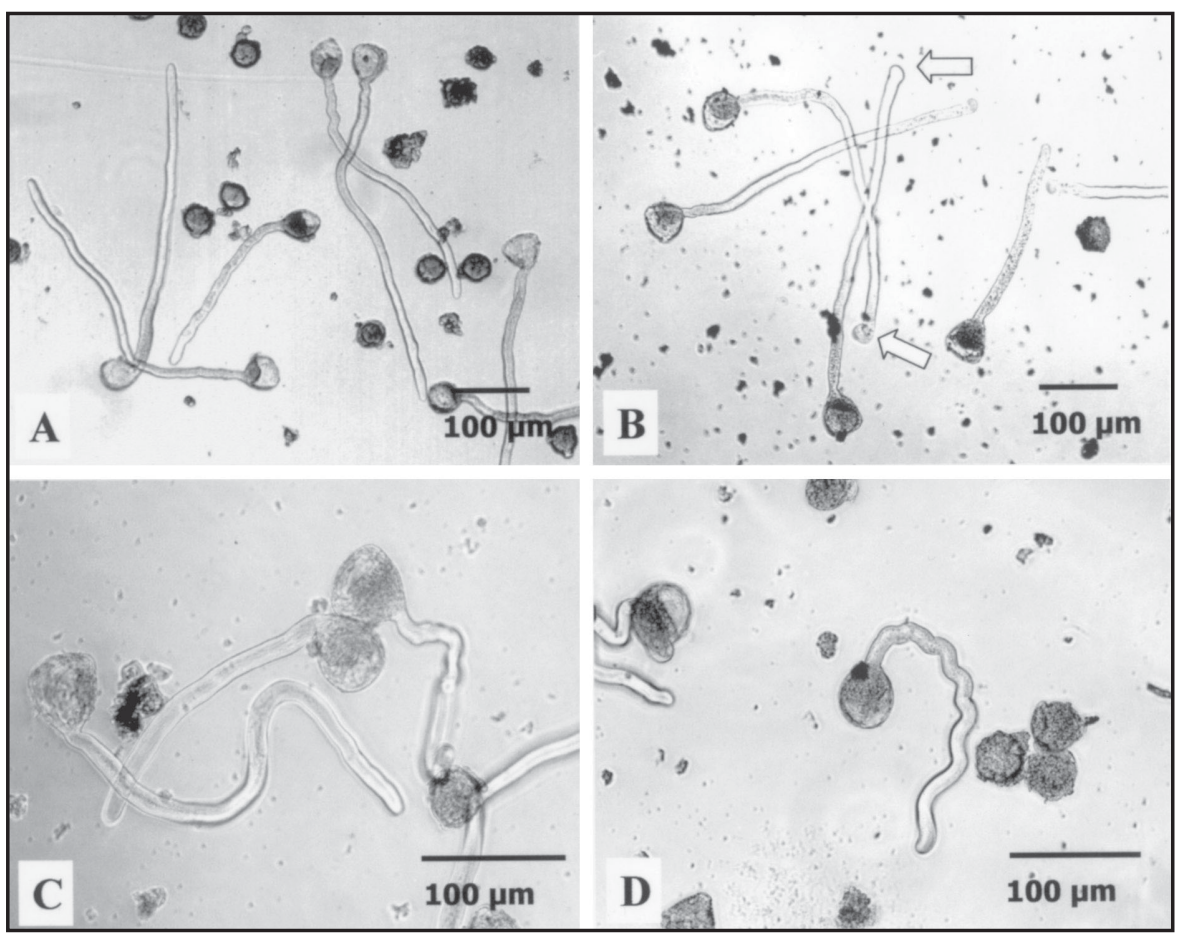

Fig. 1. Almond pollen tube morphology after $2.5 \mathrm{~h}$ incubation into germination medium with or without fungicides: (A) pollen germinated in the medium with no fungicide; (B) pollen germinated in medium with benomyl, arrows showing swelling and rupture at the tip region of pollen tube; (C) pollen germinated in medium with myclobutanil; and (D) pollen germinated in medium with propiconazole. Pollen was germinated with $1 \%$ recommended field rate of each fungicide.

and microtubules. In some situations, pollen tube growth and vigor may influence successful fertilization. If pollen were to exhibit divergent growth patterns in vivo, fungicides may impact successful fertilization.

A number of compounds tested included fungicides in the same chemical class, i.e., two azoles, two benzimidazoles, two dicarboximides, and two dithiocarbamates were evaluated. Some generalities were observed related to chemical class. The azole compounds (myclobutanil and propiconazole) exhibited no or very limited inhibition of pollen germination and tube growth. The benzimidazoles (benomyl and thiophanate-methyl) had noto-intermediate effects. The dithiocarbamate compounds (maneb and ziram) and the pyrimidine (cyprodinil) more severely suppressed pollen germination and growth. Azoxystrobin, a strobilurin, was highly inhibitory. In contrast, the two dicarboximides (iprodione and captan) were highly variable in their effect on pollen germination and tube growth. This indicates the necessity to evaluate new fungicide products on an individual basis.

This study provided data on the relative toxicity of different classes of fungicides on pollen germination and tube growth in almond. Several compounds were identified (i.e., propi- conazole, benomyl, and myclobutanil) that had little or no inhibition on pollen function. Likewise, several compounds severely suppressed pollen germination (i.e., azoxystrobin and captan). It should be noted that effects of will be affected by additional considerations, such as the persistence of the chemical, whether or not it is systemic, and how it may interact with the constituents of the stigmatic papillae. In the absence of field evaluations, particularly in the case of new chemical formulations, in vitro germination studies may provide insight into how specific chemicals may impact pollination processes and further guide in vivo studies. Conditions may arise where effective disease control can be obtained by a number of fungicides. Particularly under situations where pollination may be limiting, important benefits may accrue by selecting fungicides that have the least detrimental impact on pollen germination and tube growth.

\section{Literature Cited}

Butt, D.J., A.A.J. Swait, and Joyce D. Robinson. 1985. Effect of fungicides on germination of apple and pear pollen. Ann. Appl. Biol. 106 Suppl.:110-111.

Church, R.M. and R.R. Williams. 1977. The toxicity fungicides on pollen under in vivo conditions to apple pollen of several fungicides, as demonstrated by in vivo and in vitro techniques. J. Hort. Sci. 52:429-436.

Dag,A., D. Eisenstein, and S. Gazit. 2003. The effect of fungicides used to control powdery mildew in mango on pollen germination and pollen-tube growth. Proc. 45th Intl. Soc. Trop. Hort., Lima, Peru. (In press.)

Eaton, G.W. 1961. Germination of sweet cherry (Prunus avium L.) pollen in vitro as influenced by fungicides. Can. J. Plant Sci. 41:740-743.

Eaton, G.W. and L.I. Chen. 1969. The effect of captan on strawberry pollen germination. J. Amer. Soc. Hort. Sci. 94:558-560.

Gomez, K.A. and A.A. Gomez. 1984. Statistical procedures for agricultural research. Wiley, New York.

He, Y., B.A. Palevitz, and H.Y. Wetzstein. 1996. Pollen germination, tube growth and morphology, and microtubule organization after exposure to benomyl. Physiol. Plant 96:152-157.

He, Y. and H.Y. Wetzstein. 1994. Pollen degeneration and retarded leaf development from fungicidal sprays applied during microspore development and shoot expansion. J. Hort. Sci. 69:975-983

He, Y., H.Y. Wetzstein, and B.A. Palevitz. 1995. The effects of a triazole fungicide, propiconazole, on pollen germination, tube growth and cytoskeletal distribution in Tradescantia virginiana. Sex. Plant Reprod. 8:210-216.

Kearns, C.A. and D.W. Inouye. 1993. Techniques for pollination biologists. Univ. Press of Colorado, Niwot.

Koller, W. 1987. Isomers of sterol synthesis inhibitors: Fungicidal effects and plant growth regulator activities. Pestic. Sci. 18:129-147.

Legge, A.P. and R.R. Williams. 1975. Adverse effects of fungicidal sprays on the pollination of apple flowers. J. Hort. Sci. 50:275-277.

Lockhart, C.L. 1967. Effect of fungicides on germination of lowbush blueberry pollen and on number of seeds per berry. Can. Plant Dis. Surv. 47:72-73.

Marcucci, M.C. and N. Filiti. 1984. Gemination of pear and apple pollen as influenced by fungicides. Gartenbauwissenschaft 49:29-32.

Mayer, D.F. and J.D. Lunden. 1986. Toxicity of fungicides and an acaricide to honey bees (Hymenoptera: Apidae) and their effects on bee foraging behavior and pollen viability on blooming apples and pears. Environ. Entomol. 15:1047-1049.

Ogawa, J.M. and H. English. 1991. Diseases of temperate zone tree fruit and nut crops. Publ. 3345, Univ. of California, DANR, Oakland.

Ploetz, R.C., G.A. Zentmyer, W.T. Nishijima, K.G. Rohrbach and H.D. Ohr. 1994. Compendium of tropical fruit diseases. APS Press, St. Paul, Minn.

SAS Institute, Inc., 1989. SAS/SAT user's guide. Vol 2, ver. 6. 4th ed. SAS Inst., Cary, N.C.

Wetzstein, H.Y. 1990. Stigmatic surface degeneration and inhibition of pollen germination with selected pesticidal sprays during receptivity in pecan. $\mathrm{J}$. Amer. Soc. Hort. Sci. 115:656- 661.

Wetzstein, H.Y., E.A. Richardson, and Y. He. 2002. Alterations in anatomy and ultrastructure of pecan leaves treated with propiconazole during shoot expansion. J. Amer. Soc. Hort. Sci. 127:8-12. 